\title{
Una metodologia integrata per la documentazione e rappresentazione dei teatri emiliani danneggiati dal sisma del 2012
}

\author{
Marcello Balzani \\ Martina Suppa
}

Abstract

Il contributo illustra la metodologia integrata estensiva da applicare sull'area del cratere emiliano colpito dal sisma nel 2012, focalizzandosi sui beni culturali e nello specifico sui teatri tutelati danneggiati. Attraverso le procedure integrate di rilievo - eidotipi metrico-geometrici, rilievi topografi, sistemi GIS, sistemi LIDAR, fotogrammetria, termografia - si propone un approccio olistico con l'obiettivo di ottimizzare e sistematizzare le informazioni finora archiviate, nonché implementare dati e metadati, servendosi della piattaforma interoperabile e implementabile HBIM INCEPTION. La ricerca si propone di formulare un protocollo integrato del rilievo del danno sismico declinato sulla tipologia dei teatri, uno strumento operativo in fase di emergenza e programmatico per la conservazione preventiva. II protocollo integrato di rilievo del danno sismico mira a documentare organicamente i teatri storici su scala regionale. La presente ricerca è condotta all'interno del XXXIV ciclo del dottorato internazionale IDAUP. Finanziata dai fondi sociali europei dell'Operativo Programma 20 /4/2020 Regione Emilia-Romagna - elevate competenze per la ricerca, al trasferimento tecnologico e commerciale -, è coordinata dal Centro DIAPReM dell'Università di Ferrara in concerto con l'Agenzia per la Ricostruzione dell'Emilia-Romagna-Sisma 2012 e si awale della rete alta tecnologia dell'Emilia-Romagna, dei laboratori TekneHub e del network Clust BUIL edilizia e costruzioni.

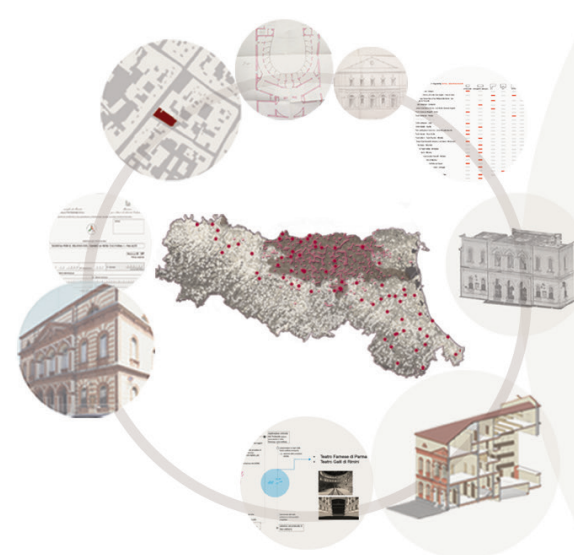

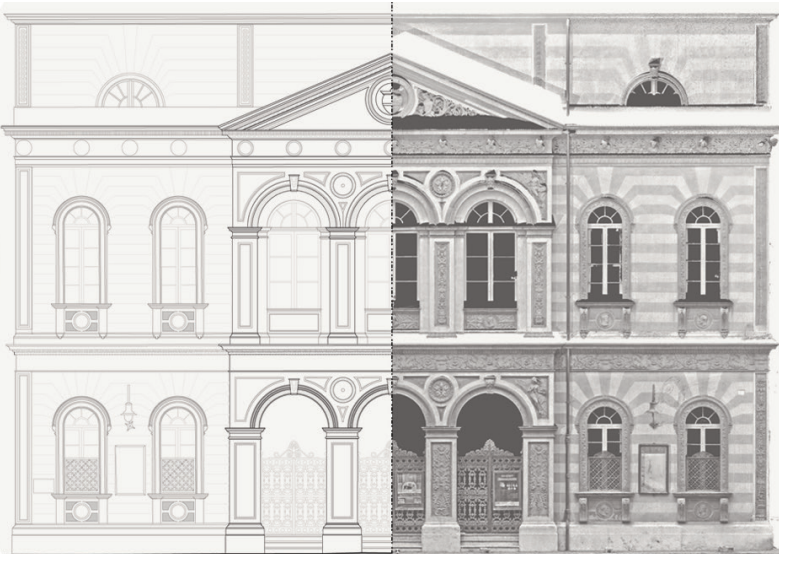

doi.org/ $0.3280 /$ oa-548.9 


\section{Introduzione}

II sisma del 20I2, che ha colpito le province di Reggio-Emilia, Modena, Bologna e Ferrara, ha mostrato la necessità di documentare - rilevare, rappresentare e interpretare - il patrimonio culturale regionale. L'evento ha evidenziato la fragilità (Libro 2019) del tessuto storico-architettonico regionale, legata alle modalità costruttive, povertà di materiali, continue modifiche e cambi di destinazioni d'uso, fatto che ha influenzato i consistenti danni al patrimonio regionale [Coïsson, Ferrari 2019]. Al fine di garantire un livello di conoscenza accurata LC3 (PP 617, 2009) l'impiego di un approccio olistico integrato rappresenta uno strumento di documentazione e analisi attraverso il quale è possibile indagare e restituire gli aspetti morfo-metrici, geometrici, stratigrafici costruttivi, strutturali, fessurativi e di degrado per raggiungere una conservazione preventiva e programmata per una mitigazione del rischio sismico. Attraverso l'utilizzo delle metodologie di rilievo integrate, in riferimento al quadro normativo che vede il rilievo geometrico come atto essenziale per la definizione dei 'livelli di conoscenza', la ricerca propone l'applicazione delle tecnologie del rilievo digitale esistenti - stazione totale, laser scanner 3D, fotogrammetria digitale, sistema GIS - integrandoli con la modellazione semantica dei dati in ambiente H-BIM. Su un campione di esperienze dirette - $i$ teatri emiliani danneggiati dal sisma- lo studio propone come output finale di definire un protocollo di rilievo integrato del danno, che dalla fase di acquisizione, interpretazione elaborazione, fino alla verifica e validazione dei dati e metadata, ha lo scopo di implementare strumenti e procedure correnti del rilievo del danno sismico garantendo il monitoraggio dinamico e la conservazione sostenibile e preventiva del patrimonio culturale regionale.

\section{Workflow}
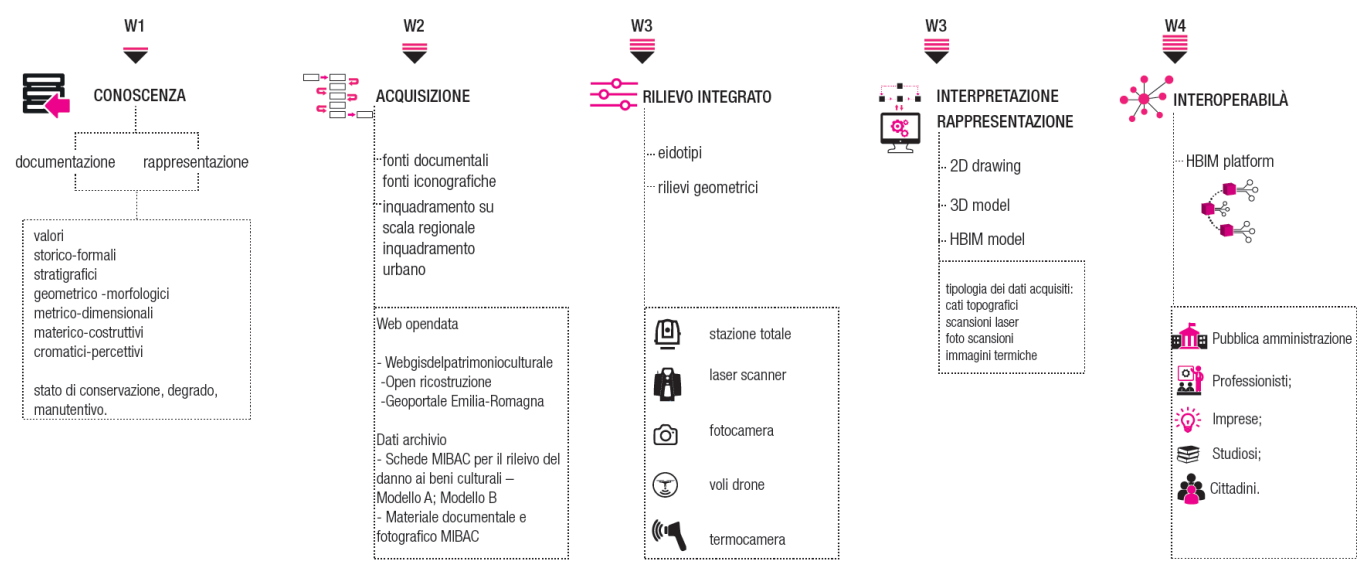

\section{Una metodologia integrata estensiva}

Lo studio finora condotto si è articolato in due principali fasi di analisi: la prima riguardo all'analisi del 'modello della ricostruzione' proposto dall' Emilia-Romagna, la seconda, declinata al primo campionamento sistematico e analitico dei 3 I teatri danneggiati.

II 'modello della ricostruzione', messo in atto dall'Agenzia per la ricostruzione - SISMA 20 I2, ha promosso l'introduzione di specifiche procedure e strumenti digitali per la gestione dell'emergenza. Partendo dagli applicativi Moka GIS, applicazioni web GIS fruibili da un browser standard basate sul motore ArcGIS Server di ESRI, si è provveduto alla progressiva sostituzione della banca dati cartacea in database informativi digitali, consentendo la digitalizzazione dei dati e dei procedimenti tecnico-amministrativi e un sostanziale miglioramento della gestione dellintero iter della ricostruzione [Balzani, Raco, Suppa 2019]. Definite le 
priorità di intervento della governance regionale [Cocchi 20I6] sono state sviluppate tre piattaforme interoperabili: MUDE, SFINGE, FENICE, rispettivamente dedicate alla gestione dei contributi per la ricostruzione delle abitazioni private, delle imprese e delle opere pubbliche. I dati raccolti nelle piattaforme dedicate, successivamente, sono confluiti nel Database Unico della Ricostruzione - DURER - contenitore unico informatico che ha consentito di riunire la pluralità dei soggetti coinvolti, monitorando l'intero processo di ricostruzione. In particolare, la ricostruzione dei beni culturali ha rappresentato il tassello finale dell'intero processo, in quanto l'iter della predisposizione e attivazione del Programma delle Opere pubbliche e dei Beni Tutelati è stato subordinato ad una puntuale ricognizione dello stato dell'arte del patrimonio culturale danneggiato dal sisma, circa l'80\% sulla scala territoriale. In questo contesto significativo e di supporto alle campagne di rilievo sul campo è stato il primo mapping digitalizzato attuato mediante lo sviluppo della piattaforma webGIS del Patrimonio Culturale della Regione Emilia-Romagna del Segretariato Regionale del MiBACT, al fine di localizzare, identificare e categorizzare per tipologia architettonica lo stato del patrimonio tutelato regionale all'indomani del sisma.

Secondo punto nodale di analisi è stato lo studio degli attuali strumenti di rilievo del danno sismico per i Beni Culturali. La scelta del caso di studio dei teatri è stata indicata dall'Agenzia per la Ricostruzione SISMA 2012 in quanto tuttora, nella dimensione territoriale, dopo i luoghi di culto, rappresentano luoghi identitari e di aggregazione per le comunità locali. Le stesse amministrazioni pubbliche infatti, sono state portatrici d'interesse nell'avviare le procedure per la ricostruzione delle strutture teatrali presenti nei rispettivi territori. Pertanto, sono state analizzate le schede del danno dei 3 I teatri danneggiati: 25 relative ai teatri storici tutelati e 6 riguardanti sale teatrali connesse a sale parrocchiali.

Questo primo campionamento ha mostrato che per la restituzione del quadro del danno in relazione alla tipologia teatro sono state compilate in prevalenza schede ministeriali B-DP (palazzi), mentre solo per il teatro comunale di Pieve di Cento e il teatro di Guastalla i funzionari competenti (Libro 2019, DPCM 55, 2006) hanno ritenuto necessario l'implementazione della scheda B con il modello A-DC (chiese) per descrivere unitariamente lo stato del danno. I due strumenti schedografici, seppur consentendo in fase di emergenza un primo rilievo speditivo, attraverso l'identificazione dei meccanismi di collasso attivatisi sotto

9614 Beni architettonici presenti su scala regionale

1433 beni archittonici danneggiati dal sisma 2012

\section{5 teatri presenti su scala regionale}

31 teatri danneggiati

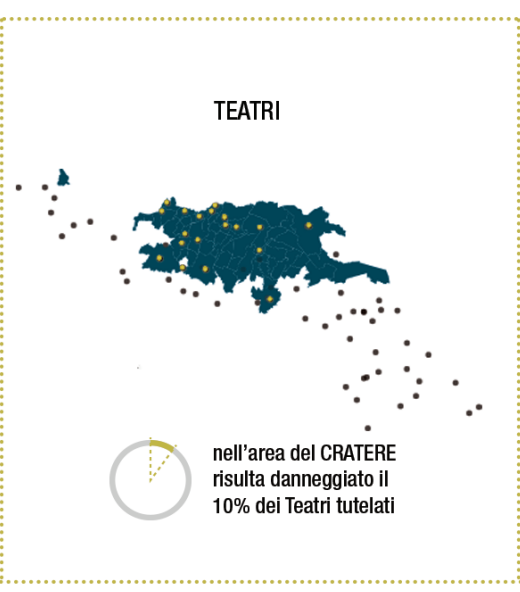

EDFCI REULIOS

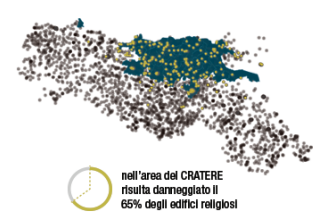

PALAZI
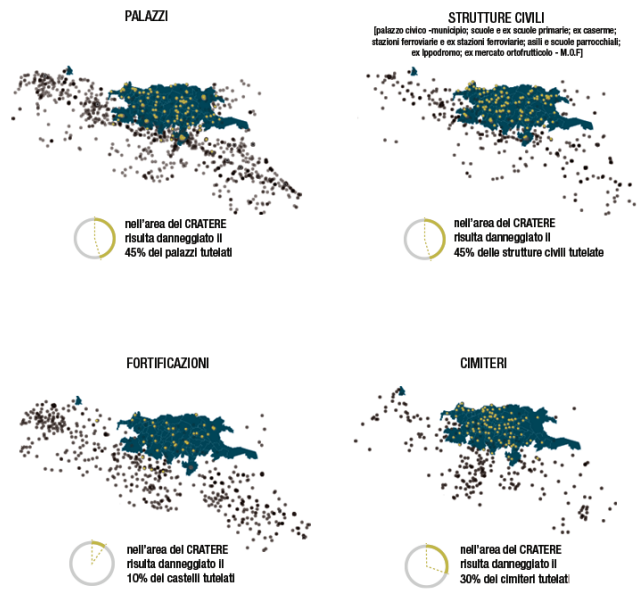
l'azione sismica (28 meccanismi di colosso per la scheda A-DC, 22 per la scheda B-DP), e la stima dell'indice del danno, sono risultati insufficienti nel restituire una documentazione esaustiva dei danni riscontrati utile ai fini progettuali e conservativi.

Infatti, la struttura compilativa dei modelli schedografici per l'analisi della tipologia architettonica analizzata ha riscontrato la perdita di informazioni quantitative e qualitative come la stratigrafia storica, dei materiali, delle tecniche costruttive, della stessa storia simica degli edifici [Cö̈sson, Ferrari 2019].

Nel garantire un'azione di prevenzione e di conservazione dei teatri dalla macro scala regionale alla micro scala architettonica, è necessario applicare un processo di mappatura multi-scalare, multi-livellare e criteriale che, rispondendo a criteri omogenei, documenti e restituisca i valori specifici geografico-spaziali, tipologici, storici, morfologici, geometrici, tecno-costruttivi, stratigrafici - includendo in essi le modifiche subite nel tempo per rispondere agli adeguamenti funzionali, impiantistici e interventi di restauro. Questi aspetti nella loro complessità possono essere indagati mediante l'applicazione dell'approccio olistico delle metodologie integrate di rilievo, che permettono di documentare, classificare ed editare i caratteri specifici indispensabili per rispondere ad adeguate soluzioni progettuali conservative [Maietti 2019].

Pertanto, nell'ottica di documentare il campione dei 25 teatri tutelati danneggiati del cratere emiliano, la metodologia proposta si articola in fasi conoscitive dal diverso grado di attendibilità, alle quali si affianca l'applicazione progressiva delle procedure integrate al fine di costruire un database digitale dei teatri regionali per definire un modello interpretativo digitale interoperabile e implementabile, consentendo la documentazione, la restituzione e l'interpretazione di dati e informazioni quantitative, qualitative e semantiche. In una logica progressiva analitica è necessario definire una matrice di classificazione degli specifici valori e significati dell'oggetto: tipo, forma e dimensioni, informazioni geo-spaziali, storico-artistiche, informazioni tecnologico-costruttive, alterazioni strutturali o decorative e relativo stato di conservazione [Maietti, Ferrari, Medici, Balzani 2016]. In tal senso la ricerca sviluppa una tassonomia sulla base dell'individuazione di criteri omogenei, sintetizzando il modello di classificazione ICCD con gli standard europei definiti dal progetto eu-chic [Kioussi 20 I2]. Tale classificazione costituisce la premessa per giungere all'elaborazione del modello interpretativo geometrico-architettonico, che rappresenta la base morfo-metrica per le successive analisi, fornendo informazioni di dettaglio sullo stato di fatto dell'oggetto, dalla stratigrafia storico-architettonica, tecnologica-strutturale, alla lettura del quadro fessurativo, dei dissesti e delle superfici, degli elementi strutturali, fino allindividuazione degli interventi di consolidamento realizzati in passato, la cui identificazione è basilare per la comprensione del comportamento statico-dinamico e quindi la mitigazione del rischio sismico. Nel giungere alla definizione di un protocollo integrato per il rilievo del danno sismico, la metodologia illustra la necessità di sistematizzare e pianificare le fasi di acquisizione, restituzione e interpretazio-

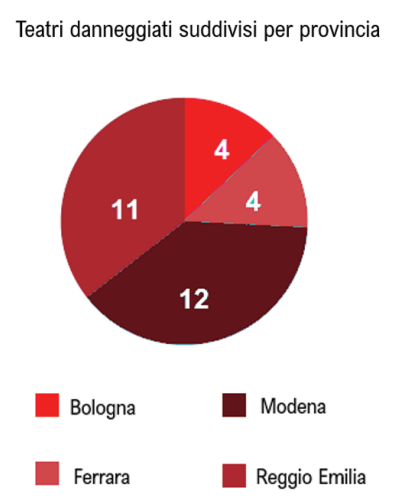

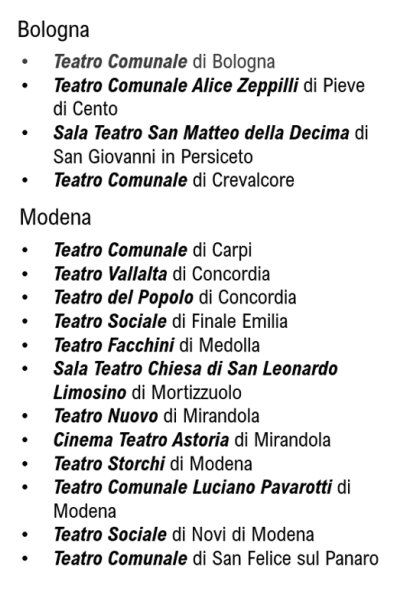

Ferrara

- Teatro Comunale di Ferrara

Teatro Nuovo di Ferrara

Teatro Comunale Borgatti di Cento Sala Teatro - Chiesa di San Nicola Vescovo - Argenta

Reggio Emilia

- Teatro Comunale Bonifazio Asioli di

Correggio

- Torreggio

Teatro Comunale Ruggero Ruggeri di

Guastalla

Teatro Gonzaghesco di Luzzara

Rocca dei Gonzaga di Novellar

Teatro Comunale di Reggiolo

Teatro Municipale Romolo Valli di Reggio

Emilia

Teatro Zavattini di Reggio Emilia

Teatro Ariosto di Reggio Emilia

Teatro Comunale di Rio Saliceto

Teatro Herberia di Rubiera 
ne dei dati raccolti in relazione alle tecniche e ai dispositivi di rilievo utilizzati per classificare una matrice di standard omogenei per l'elaborazione di modelli interpretativi utilizzabili e verificabili in tutte le fasi d'intervento.

Al fine di calibrare il metodo integrato su un'esperienza diretta, la ricerca in corso propone un campionamento progressivo delle informazioni storiche, materiche, tecnico costruttive, delle metodologie e tecnologie impiegate post sisma dai professionisti al fine di tracciare un quadro sistematico delle procedure di rilievo integrato, messe in campo per rilievi del danno sismico e rilievo diagnostico. Dal primo campione analizzato, utilizzando dapprima le informazioni sintetiche provenienti dalle schede MiBACT, si è proceduto alla sistemazione dei dati raccolti mediante database Access, correlando informazioni dall'epoca di costruzione e dei materiali di costruzione ai meccanismi di collasso attivatesi per azione sismica. Quest'analisi è stata integrata da ricerche d'archivio e documentali che hanno consentito di rintracciare informazioni sugli aspetti costruttivi e morfologici nonché sulle modifiche subite nel corso del tempo, legate a interventi di restauro conservativo per adeguamenti strutturali e impiantistici conseguenziali a esigenze funzionali o interventi di consolidamento post sisma. Contestualmente, procedendo per campioni, sono indagate le metodologie e le tecniche di rilievo utilizzate dai professionisti per le fasi conoscitive e di progetto.

Dal primo campionamento a fronte di un inquadramento topografico comune ai casi studio indagati, si riscontra che, ad eccezione del teatro Borgatti di Cento e del teatro Nuovo di Mirandola (per i quali il modello metrico geometrico è stato ricavato con acquisizione LIDAR) la restante parte ha verificato a campione il rilievo geometrico messo a diposizione dagli uffici tecnici comunali.

Per il rilievo di dettaglio, diagnostico e strutturale, limitato alle porzioni danneggiate sono state eseguite indagini integrative non distruttive, quali documentazione fotografica, termografie, ispezioni acustiche, la maggior parte delle quali effettuate in corso d'opera, causa l'impossibilità di svolgere le verifiche in sicurezza prima dell'inizio dei lavori, specie nell'area a ridosso del plafone e dell'arco scenico. Mentre durante la fase di intervento il monitoraggio è stato garantito tramite flessimetri, fessurimetri e igrometri.

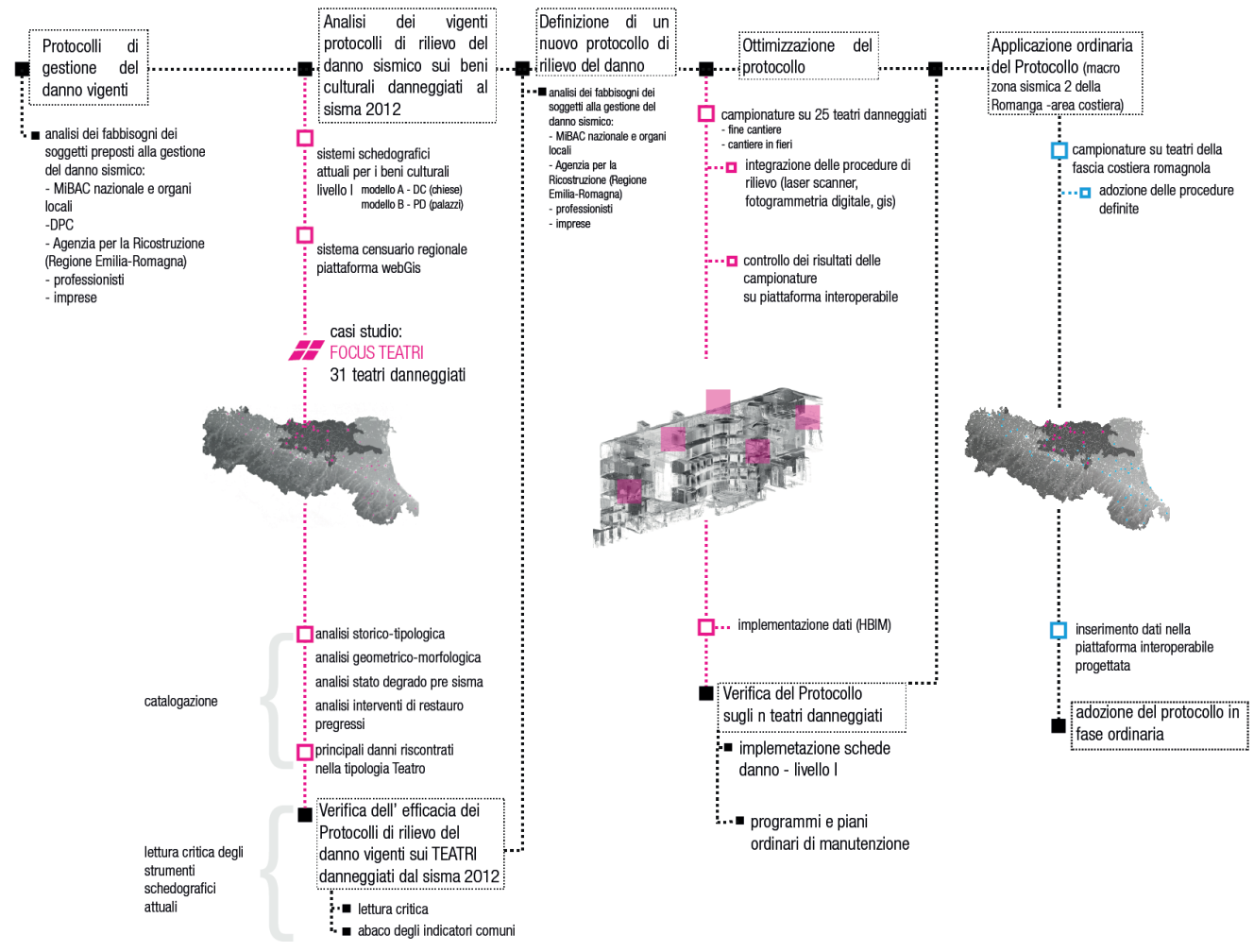




\section{Caso pilota Zero}

Al fine di giungere alla verifica della metodologia estensiva integrata di rilievo, è prevista l'applicazione operativa sul caso pilota zero del teatro comunale di Novi di Modena, non ancora rilevato. Metodologicamente, per questo caso, sono state pianificate le fasi di rilievo seguendo un workflow di analisi multi-criteriale e multi-scalare, che saranno verificate e implementate in fase operativa. Presupposto delle operazioni di rilievo sull'oggetto architettonico è la matrice di classificazione che identifica tre macro-blocchi volumetrici: foyer, cavea - tripartita in platea, palcoscenico e retropalco - e camerini come sezioni distintive della tipologia teatro sia nell'impianto morfologico, che statico-strutturale e impiantistico. Dalle campionature analitiche è emerso, infatti, che il comportamento statico dei foyer e dei camerini può assimilarsi a quello di un edificio, diversamente dalla cavea la cui risposta statico-dinamica è assimilabile ad un'aula di chiesa.

A partire da un inquadramento cartografico GIS tramite la piattaforma del Segretariato Regionale, si passa a definire la rete topografica quale strumento di controllo alla quale appoggiare il rilievo LIDAR. La lettura stratigrafica delle macro-sezioni consente di definire, pertanto, la classificazione dei macro-elementi, su cui categorizzare la nuvola di punti, utile a informare la complessa modellazione e gestione di informazioni geometriche e semantiche del relativo modello BIM [Scianna, La Guardia, Scaduto 2016]. Per le indagini di dettaglio sulle superfici maggiormente danneggiate, in particolare nell'area del ridotto, palcoscenico, arco scenico e del plafone (nei punti accessibili), è programmata l'integrazione con tecnica fotogrammetrica e termografica. La mappatura delle superfici, propedeuticamente precedute da eidotipi, consente una classificazione di dettaglio di porzioni del teatro, individuando i possibili interventi subiti nel corso del tempo.

Fig. 5. Lettura critica della scheda del danno sul caso studio del Teatro Nuovo di Mirandola.
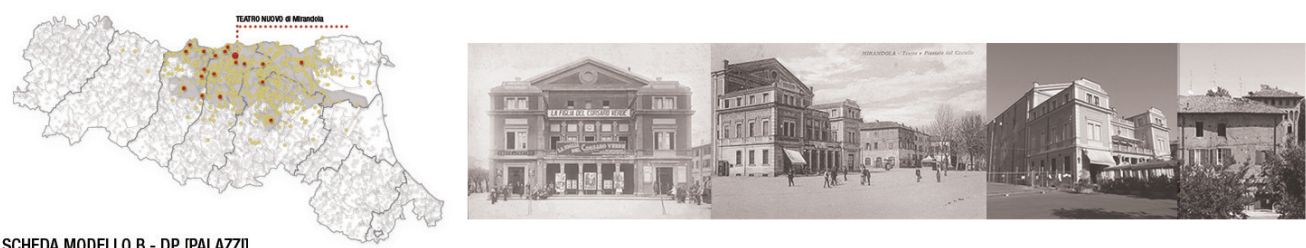

SCHEDA MODELLO B - DP [PALAZZ] D.P.C.M 23 Febbraio 2006

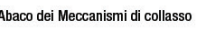

M1. ribaltamento della facciata

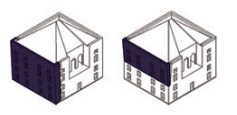

M3. rottura a flessione delle pareti

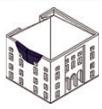

Livelli di Danno

1 - danno lieve

2 - danno moderato

3 - danno grave

4 - danno molto grave
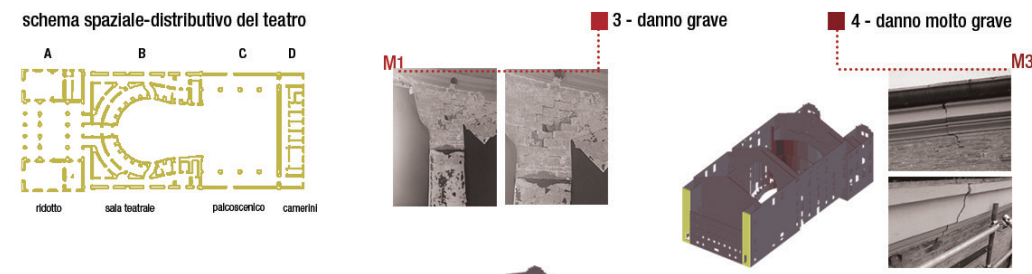

\section{Conclusioni}

La sistematizzazione dei dati raccolti dalle schede ministeriali e dalle banche dati GIS regionali, delle informazioni semantiche desunte da fonti documentali e d'archivio comprende l'integrazione delle informazioni geometrico-stratigrafiche derivate dai rilievi effettuati sui singoli teatri. Attraverso questo step, ora in fieri, si tracceranno quadri comparativi delle tecniche, delle tecnologie e dei metodi applicati con lo scopo di sintetizzare e classificare 
Fig. 6. Sistemazione del dati raccolti mediante database Access: analisi dei dati sulla tipologia muraria in relazione a meccanismi di collasso verificatesi.

\section{Analisi critica della scheda}

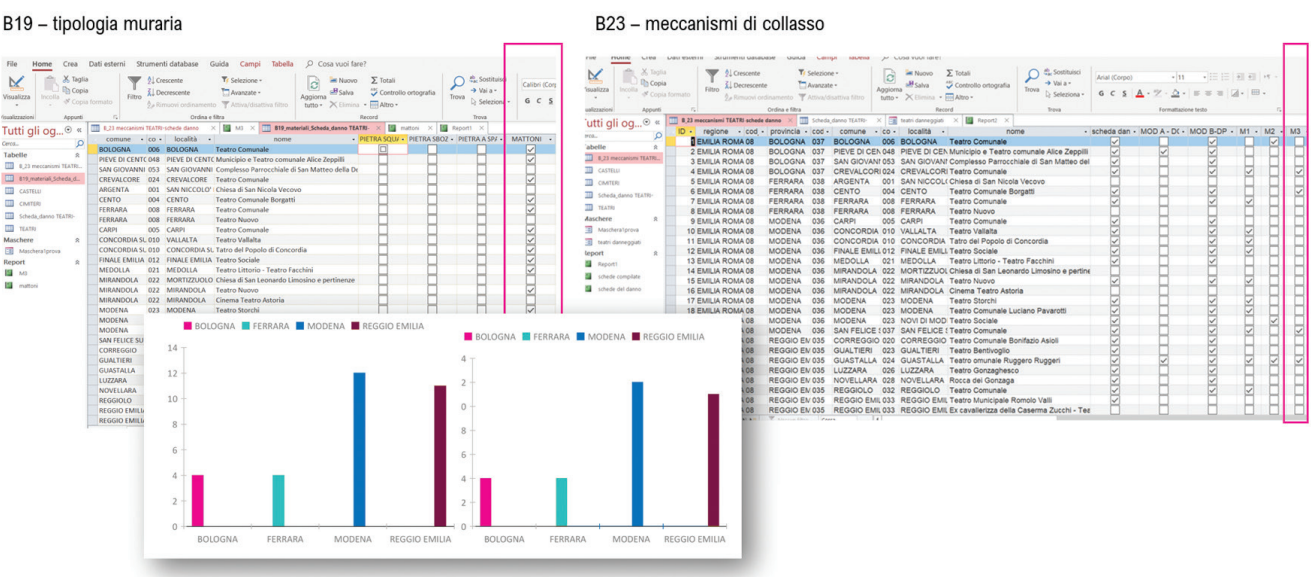

idiomi della rappresentazione, codici della catalogazione e sintassi metodologica dell'approccio integrato, finalizzati alla costruzione e verifica del protocollo. Nel fornire un quadro complessivo del workflow della ricerca va, infine, esplicato che operativamente si intende attuare la sistematizzazione delle informazioni utilizzando la piattaforma INCEPTION HBIM. La realizzazione di un campione di modelli ifc, caricati nella piattaforma interoperabile, è finalizzata all'implementazione di informazioni qualitative e quantitative, fornendo alle autorità competenti e ai professionisti un unico strumento digitale integrato. I modelli ifc, standardizzati secondo il protocollo, sono sviluppati in relazione alla classificazione dei macro-elementi, provenienti dalla matrice tassonomica al fine di implementare le informazioni sul rischio sismico allinterno del modello. Definiti i criteri omeogeni estensivi di analisi sulla campionatura dei teatri danneggiati, la ricerca propone lo sviluppo di un set di regole, finalizzate al Clash Detection e al Code Checking del modello BIM, per la verifica e convalida del modello [Balzani, Suppa 2020].

\begin{tabular}{|c|c|c|c|c|c|c|c|c|}
\hline \multicolumn{2}{|l|}{ ID Teatro } & \multirow{2}{*}{ schede del danno } & \multirow{2}{*}{ verifica rilievo geometrico 2d esistente } & \multirow{2}{*}{ stazione totale } & \multirow{2}{*}{ laser scanner } & \multirow{2}{*}{ fotocamera } & \multirow[t]{2}{*}{ voli drone } & \multirow[t]{2}{*}{ temocamera } \\
\hline FE_CENTO & $\begin{array}{l}\text { Teatro Comunale } \\
\text { Borgatti }\end{array}$ & & & & & & & \\
\hline MO_MIRANDOL & Teatro Nuovo & & 故 & 바 & & రి & (3) & \\
\hline RE_GUASTALLA & \begin{tabular}{|l|} 
Teatro \\
Comunale R. \\
Ruggeri \\
\end{tabular} & $\square_{A / B}$ & 師舟 & 발 & & ช0. & & \\
\hline RE_NOVELLARA & \begin{tabular}{|l|} 
Teatro Rocca \\
dei Gonzaga
\end{tabular} & $\angle 8$ & 故 & (하 & & (6) & & \\
\hline RE_REGGIOLO & $\begin{array}{l}\text { Taetro Comuale } \\
\text { G. Rinaldi }\end{array}$ & $\stackrel{A}{B}$ & 副 & (하 & & ర్రి & & \\
\hline
\end{tabular}

\section{Riferimenti bibliografici}

Balzani Marcello, Raco Fabiana, Suppa Martina (2019). Protocolli di acquisizione e gestione dati per la documentazione, rappresentazione e conservazione del patrimonio culturale danneggiato dal sisma. In Paesaggio Urbano, I, 20 I 9, pp. I6I-I69.

Balzani Marcello, Suppa Martina (2020). Integrated survey procedures: a methodological approach for documentation and representation applied to Emilia-Romagna theatres. In International Conference, HeriTech 2020, The Future of Heritage Science and Technologies, International Conference, Florence, 2020 (being published)

Bold John and ed. (2009). Guidance on inventory and documentation. Council of Europe, 2009. 
Bolognesi Cecilia Maria (2019). Un parco di sperimentazioni: Applicazioni di rilievo e modellazione per la costruzione di ambienti virtuali in Cultural Heritage. In Paesaggio Urbano, 3, 2019, pp. 57-67.

Bondoni Simonetta Maria (1982). Teatri storici in Emilia-Romagna. Bologna: Grafis.

Bonsma Peter, Bonsma Iveta, Sebastian Rizal, Maietti Federica et al. (20 I6). Roadmap for IT research on a Heritage-BIM Interoperable Platform within INCEPTION. In Borg Ruben Paul, Gauci Paul, Staines Cyril Spiteri (eds.). Proceedings of the International Conference, SBE, Malta, Europe and the Mediterranean:Towards a Sustainable Built Environment, I 6th- I 8th March 20 I 6-Valletta: Gutenberg Press, pp. 283-290.

Cocchi Enrico (2016). La ricostruzione post sisma 2012 in Emilia-Romagna: Quale contributo alla resilienza del territorio? In AA.W. Pianificazione strategica vulnerabilità urbana e analisi degli edifici strategici, Santarcangelo di Romagna: Maggioli Editore, pp. $12-14$.

Coïsson Eva, Ferrari Lia (2019). Predisposizione e studio di modelli specifici ad implementazione degli strumenti esistenti: scheda per la valutazione dei primi interventi di messa in sicurezza e rilievo del danno per tipologie architettoniche specifiche (teatri, castelli, cimiteri). In Paesaggio Urbano, I, 2019, pp. I53-I59.

DPCM 23 Febbraio 2006, n. 55 Approvazione dei modelli per il rilevamento dei danni, a seguito di eventi calamitosi, ai beni appartenenti al patrimonio culturale.

Farneti Fauzia, Van Riel Silvio (1975). L'architettura teatrale in Romagna 1757- 1857. Firenze: UNIEDIT.

Kioussi Anastasia, Karoglou Maria, Labropoulos Kyriakos, Bakolas Asterios, Moropoulou Antonia (20I2). Integrated documentation protocols able to support decision making process in cultural heritage protection. In Roko Žarnic, Vlatka Rajcic, Barbara Vodopivec. Heritage Protection. From Documentation to Interventions. Proceedings of the EU-CHIC International Conference on Cultural Heritage Preservation, Ljubljana, Slovenia 2012, pp. I29-131.

Libro Antonino (20 I 9). Il rilievo del danno al patrimonio storico-artistico e i primi interventi di messa in sicurezza. In Paesaggio Urbano, I, 2019, pp. 147-151.

Maietti Ferderica (2019). Survey and representation of historical surfaces: the coulours of Jodfhpur. In Balzani Marcello, Minakshi Jain, Rossato Luca. Between History and Memory, the Blue Jodhpur. Experiences of integrated documentation and survey techiniques. Santarcangelo di Romagna: Maggioli Editore.

Maietti Federica, Ferrari Federico, Medici Marco, Balzani Marcello (20I6). 3D integrated laser scanner survey and modelling for accessing and understanding European cultural assets. In Ruben Paul Borg, Paul Gauci, Spiteri Staines Staines. Proceedings of the International Conference, SBE, Malta, Europe and the Mediterranean:Towards a Sustainable Built Environment, I 6th- I 8th March 20 16. Valletta: Gutenberg Press, pp. 317-324.

Parrinello Sandro (20 I0). II rilievo del complesso di Monte Senario. Strategie per la documentazione e la valorizzazione. In Bertocci Stefano, Parrinello Sandro. Architettura Eremitica: Sistemi Progettuali e Paesaggi Culturali. Firenze: Edifir-Edizioni, pp. 17-33.

PP., 2 febbraio 2009, n. 617, Istruzioni per l'applicazione delle "Norme tecniche per le Costruzioni", capitolo C8 e l'Allegato A.

Remondino Fabio (20 I I). Rilievo e modellazione 3D di siti e architetture complesse. In DisegnareCon. Tecnologie per la comunicazione del patrimonio culturale, 8, 20। I, 4.

\section{Sitografia}

https://geoportale.regione.emilia-romagna.it/it

https://www.patrimonioculturale https://www.patrimonioculturale-erit/webgis/

https://sites.google.com/view/statsbyggs-bim-manual-2-0-sbm2/hjem, Statsbygg BIM Manual 2.0, EU BIMTask Group - 2019.

https://www.inception-project.eu/en, INCEPTION -Inclusive Cultural Heritage in Europe through 3D semantic modelling, Horizon 2020.

\section{Autori}

Marcello Balzani, Università degli Studi di Ferrara, bzm@unife.it

Martina Suppa, Università degli Studi di Ferrara, martina.suppa@unife.it

Per citare questo capitolo: Balzani Marcello, Suppa Martina (2020). Una metodologia integrata per la documentazione e rappresentazione dei Teatri emiliani danneggiati dal sisma del 2012/An integrated methodology for the documentation and representation of the Emilia-Romagna damaged theatres by the 2012 earthquake. In Arena A., Arena M., Brandolino R.G., Colistra D., Ginex G., Mediati D., Nucifora S., Raffa P. (a cura di). Connettere. Un disegno per annodare e tessere. Atti del $42^{\circ}$ Convegno Internazionale dei Docenti delle Discipline della Rappresentazionel Connecting. Drawing for weaving relationships. Proceedings of the 42th International Conference of Representation Disciplines Teachers. Milano: FrancoAngeli, pp. 1644-1659. 


\title{
An Integrated Methodology for the Documentation and Representation of the Emilia-Romagna Damaged Theatres by the 2012 Earthquake
}

\author{
Marcello Balzani \\ Martina Suppa
}

Abstract

The contribution illustrates the extensive integrated methodology to be applied in the area of the Emilian Crater affected by the earthquake in 20 12, focusing on cultural heritage and specifically on damaged protected theatres. Through the integrated survey procedures -metric-geometric preliminary sketch, topographic surveys, GIS systems, LIDAR systems, photogrammetry, thermography- a holistic approach is proposed to optimize and systematize the information stored so far, as well as implementing data and metadata, using the interoperable and implementable platform HBIM INCEPTION. The research aims to formulate an integrated protocol of seismic damage survey on the type of theatres, an operational tool in emergency and programmatic phase for preventive conservation. The integrated seismic damage survey protocol aims at organically documenting historical theatres on a regional scale. This research was conducted within the XXXIV cycle of the IDAUP international doctorate. Funded by the European social funds of the Operational Programme 2014/2020 Emilia-Romagna Region -high expertise in research, technology transfer and commercial- it is coordinated by the DIAPReM Centre of the University of Ferrara in concert with the Agency for the Reconstruction of Emilia-Romagna-Sisma 2012. It makes use of the Emilia-Romagna high technology network, TekneHub laboratories and the Clust BUIL building and construction network.

Keywords

documentation, integrated survey, classification, interpretation, seismic prevention.
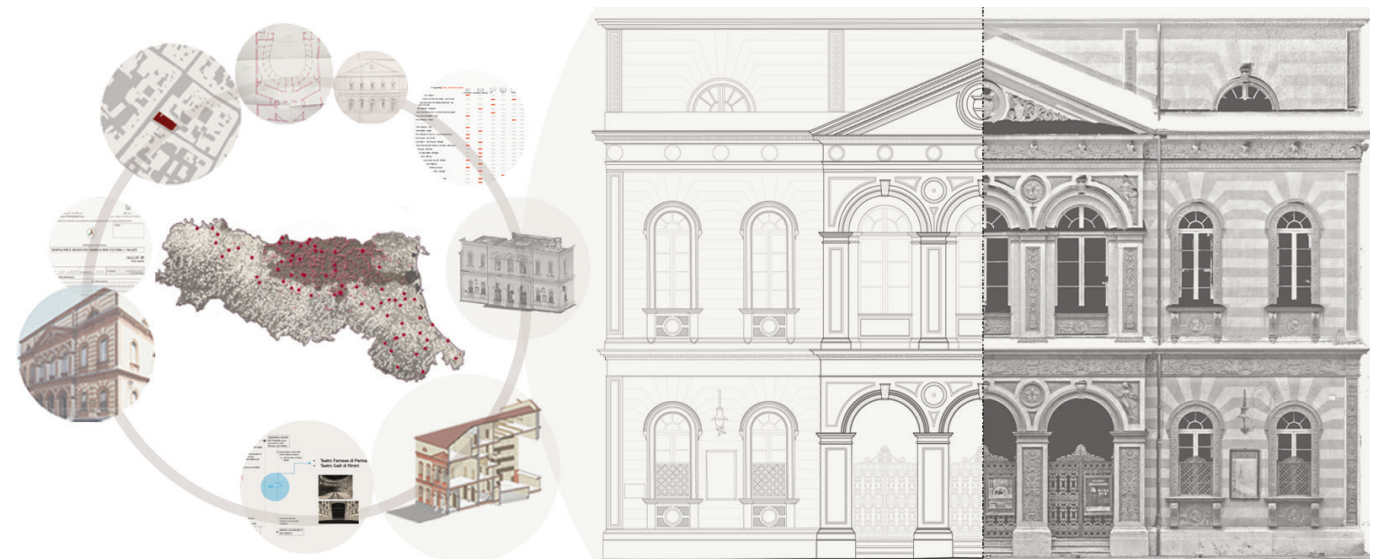


\section{Introduction}

The 2012 earthquake, which struck the provinces of Reggio-Emilia, Modena, Bologna and Ferrara, showed the need to document - detect, represent and interpret- the regional cultural heritage.

The event highlighted the fragility (Libro 2019) of the historical-architectural heritage of the region, connected to construction methods, poverty of materials, continuous transformation and modification of uses, which has influenced the consequent damage to the regional heritage [Coïsson, Ferrari 2019]. In order to guarantee an accurate-knowledge level LC3 (PP 617, 2009), the employment of an integrated, holistic approach represents a documentation and analysis tool. In order to achieve a preventive and planned conservation for seismic risk mitigation, this tool allows to investigate and represent morpho-metric, geometrical, constructive, structural, cracking and degradation stratigraphic aspects. Concerning the legislative framework that considers geometric surveying an essential document for the 'knowledge levels' integrated surveying methodologies have employed. The research presents the application of existing digital surveying technologies -total station, 3D laser scanner, digital photogrammetry, GIS system- integrating them with semantic data modelling in $\mathrm{H}$-BIM environment. Starting to a specific sample of cases study -the theatres damaged by the earthquake- the study proposes to define an integrated damage survey protocol, from the acquisition, interpretation and elaboration phase to data and metadata verification and validation, in order to implement current tools and procedures for seismic damage survey, guaranteeing dynamic monitoring and sustainable and preventive conservation of the regional cultural heritage.

Fig. I. Research project workflow.

\section{Workflow}
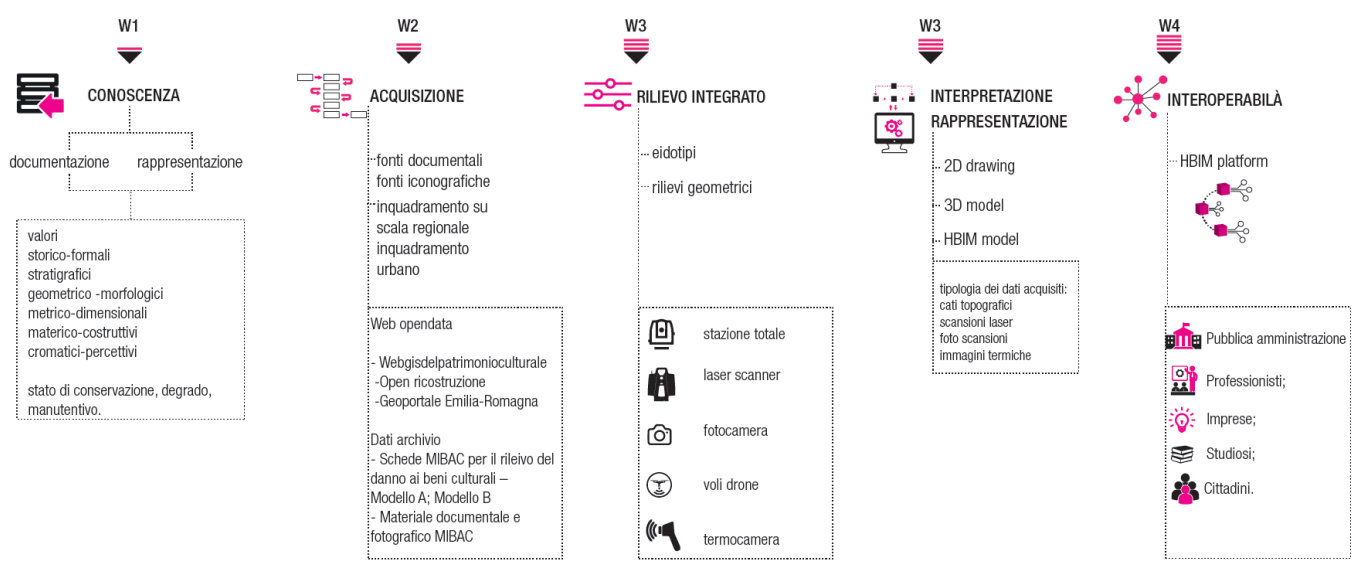

\section{Extensive integrated methodology}

The current study focuses on two main phases of analysis: the first concerning the analysis of the model of reconstruction proposed by Emilia-Romagna, the second, declined to the first systematic and analytical sampling of 31 damaged theatres.

The reconstruction model, implemented by the Agency for Reconstruction - SISMA 20I2, has promoted the introduction of specific procedures and digital tools for emergency management. Starting from the Moka GIS applications, web GIS applications usable by a standard browser-based on ESRI's ArcGIS server environment, the paper database has been upgraded into digital information databases, allowing the digitisation of data and technical-administrative procedures and a consequent improvement the entire reconstruction process management [Balzani, Raco, Suppa 2019]. Priorities for regional governance inter- 
vention have been defined [Cocchi 2016], and three interoperable platforms have developed: MUDE, SFINGE, FENICE, severally dedicated to the management of contributions to the reconstruction of private houses, businesses and public building and cultural assets. The data collected by the dedicated platforms have incorporated into Database Unico della Ricostruzione -DURER- a shared database that gathered the plurality of actors involved, monitoring the reconstruction process.

The reconstruction of the cultural heritage represents the last step of the entire process. The procedure for the Programme of Public Works and Protected Assets development and activation has been conditioned to a detailed reconnaissance of the state-of-the-art of the damaged cultural heritage, about $80 \%$ on the regional scale. In this context, the first digitalised mapping implemented through the development of the webGIS platform of the Cultural Heritage of the Emilia-Romagna Region of the Regional Secretariat of MiBACT, to locate, identify and categorise by architectural typology the state of the regional protected heritage in the post-earthquake period, represented significant support to the field survey. The second step focuses on the study of the current tools to survey seismic damage to cultural heritage. The Agency for the reconstruction SISMA 2012 indicated to select the theatre's case study: after the religious sites, they still represent, in the social dimension, symbol and place of aggregation and collective identity. The public administrations themselves, have been holders of interest to start the reconstruction procedures for the theatres re-building in their respective territories. Therefore, the damage files of the 31 damaged theatres have been analysed: 25 of them related to the protected historical theatres and 6 to the theatres connected to parish halls.

This first sampling showed that for the representation of the theatre damage framework, mainly ministry forms B-DP (palaces) has filled in. At the same time, for the municipal theater of Pieve di Cento and the Guastalla theater, only the responsible public officials (Libro 2019, DPCM 55, 2006) considered the implementation of form B with model A-DC (churches) necessary to describe the state of the damage.

The two schedographic tools, although allowing a first expeditious survey in the emergency phase, identifying the mechanisms of collapse activated by the seismic action (28 colossal mechanisms for the A-DC card, 22 for the B-DP card), and estimating the damage index,

Fig. 2. Analysis of the cultural heritage damaged by the 2012 earthquake: subdivision by architectural typology based on data gathered from the data gathered from the patrimonioculturale-erit/ webgis/>.
9614 Beni architettonici presenti su scala regionale

1433 beni archittonici danneggiati dal sisma 2012

\section{5 teatri presenti su scala regionale}

31 teatri danneggiati

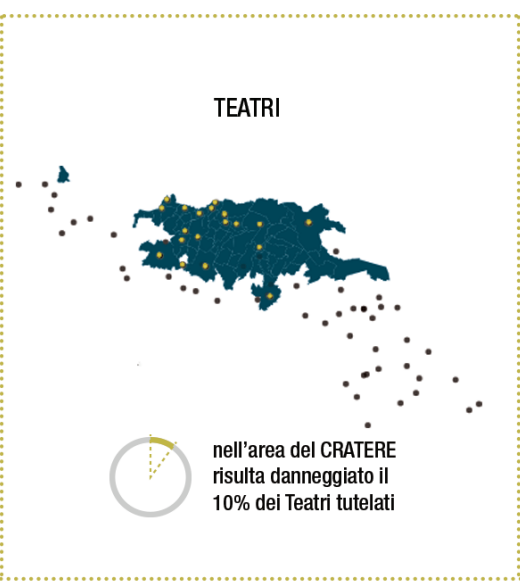

10

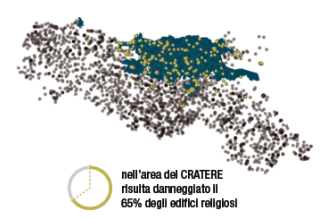

PALAZI
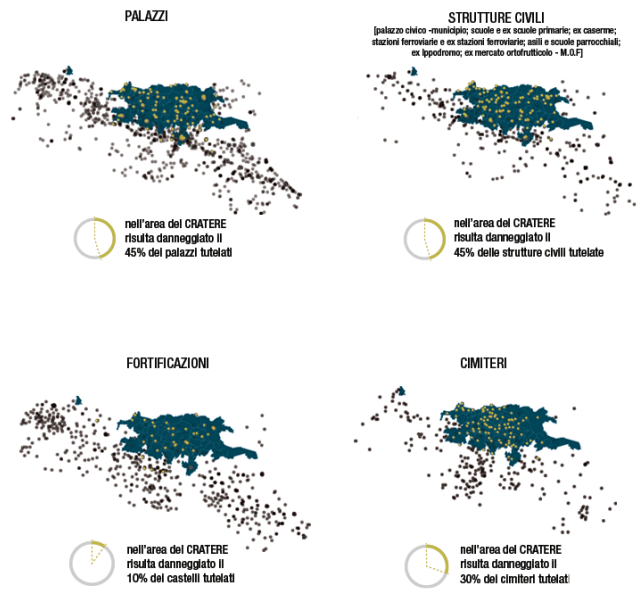
were insufficient in providing comprehensive documentation of the damage detected useful for project and conservation requirements. The compilation form of the schematic templates with architectural typology analysed resulted in the quantitative and qualitative knowledge loss, including historical stratigraphy, materials, construction techniques, and the seismic history of buildings [Coïsson, Ferrari 2019].

In ensuring theatres prevention and conservation at the regional macro-scale to the architectural micro-scale, multi-level and criteria mapping process to apply a multi-scale, multi-level, and criteria mapping is necessary. This approach allows documentation and representation of specific geographical-spatial, typological, historical, morphological, geometrical, techno-constructive, layered values including modifications over time to respond to functional, engineering and restoration interventions. In their complexity, these aspects can have investigated through the application of the holistic approach of integrated survey methodologies, which allow to document, classify and edit the specific features essential to respond to suitable conservative project solutions [Maietti 2019].

Therefore, to document the sample of the 25 damaged historic theatres of the Emilian Crater, the proposed methodology is divided into knowledge phases with different degrees of accuracy, which are supported by the developing application of integrated procedures. The aim is the development of a digital database of regional theatres to define an interoperable and implementable digital interpretation model, allowing the documentation, restitution and interpretation of quantitative, qualitative, and semantic data and information. In a progressively analytical framework, defining a classification matrix of the specific values and significances of the object, is necessary: type, shape and dimensions, geo-spatial, historical-artistic, technological-constructive information, structural or decorative alterations and relative state of conservation [Maietti, Ferrari, Medici, Balzani 20 I6]. The research develops a taxonomy based on the identification of standard criteria, sharing the ICCD classification model with the European standards defined by the EU-chic project [Kioussi 20 I2]. This classification is the premise of the geometric-architectural interpretative model development, which represents the morpho-metric basis for the subsequent analyses. The classification sets out detailed information on current health condition, from the historical-architectural, technological-structural stratigraphy, to the reading of the cracked framework, structural elements and surfaces degradation, up to the identification of the consolidation interventions realised in the past, identified as basis for the analysis of static-dynamic behaviour and, therefore, for the mitigation of seismic risk. In achieving the integrated protocol definition, the methodology illustrates the need to systematize and plan the phases of acquisition, restitution and interpretation of the data collected to the survey techniques and devices used to classify a matrix of homogeneous standards for the elaboration of interpretative models that can be used and verified in all phases of intervention.

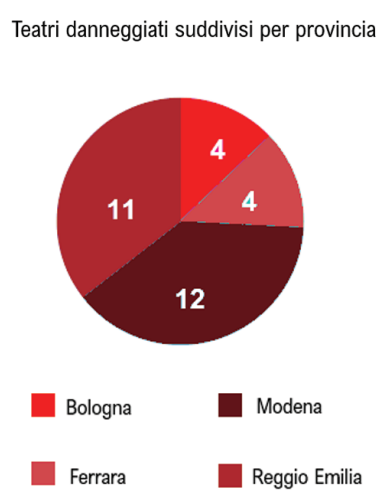

Bologna

- Teatro Comunale di Bologna

Teatro Comunale di Bologna deatro Como

Sala Teatro San Matteo della Decima di

San Giovanni in Persiceto

- Teatro Comunale di Crevalcore

Modena

- Teatro Comunale di Carpi

Teatro Vallalta di Concordia

Teatro del Popolo di Concordia

Teatro Sociale di Finale Emilia

Teatro Facchini di Medolla

Sala Teatro Chiesa di San Leonardo

Limosino di Mortizzuolo

Teatro Nuovo di Mirandola

Cinema Teatro Astoria di Mirandola

Teatro Storchi di Modena

Teatro Comunale Luciano Pavarotti d

Modena

Teatro Sociale di Novi di Modena

- Teatro Comunale di San Felice sul Panaro
Ferrara

- Teatro Comunale di Ferrara

Teatro Nuovo di Ferrara

Teatro Comunale Borgatti di Cento

Sala Teatro - Chiesa di San Nicola Vescovo - Argenta

Reggio Emilia

- Teatro Comunale Bonifazio Asioli di Correggio

Teatro Bentivoglio di Gualtieri

Teatro Comunale Ruggero Ruggeri d Guastalla

Teatro Gonzaghesco di Luzzara

Rocca dei Gonzaga di Novellar

Teatro Comunale di Reggiolo

Teatro Municipale Romolo Valli di Reggio

Emilia

Teatro Zavattini di Reggio Emilia

Teatro Ariosto di Reggio Emilia

Teatro Comunale di Rio Saliceto

Teatro Herberia di Rubiera 
In order to target the integrated method on-field experience, the ongoing research proposes a stepwise selection of historical, material, technical and construction information, methodologies and technologies used after the earthquake by professionals in order to draw a systematic overview of the integrated survey procedures used for seismic damage and diagnostic surveys. From the first examined sample, using first the summarise information coming from the MiBACT forms, the data collected through the Access database were settled, correlating information from the time of construction and construction materials to the collapse mechanisms activated by seismic action. This analysis has complemented by archive and documentary research through which it was possible to find information regarding the construction and morphological aspects as those changes undergone over time, linked to conservative restoration interventions involving structural and implantation adaptations to functional requirements or post-seismic consolidation interventions.

At the same time, proceeding by test samples, the survey methodologies and techniques used by professionals for the knowledge and project phases had investigated.

From the first collection of samples, in comparison with a topographical survey common to the case studies investigated, it is shown that, except for the teatro Borgatti in Cento and the teatro nuovo in Mirandola (for which the geometric metric model has collected with LIDAR acquisition), the remains of the sample verified the geometrical survey put at disposal by the municipal technical offices.

While, for the detailed, diagnostic and structural survey, limited to the damaged portions, additional non-destructive investigations had implemented: photographic documentation, thermography, acoustic inspections, most of which had carried out in the course of the work, due to the impossibility of carrying out the checks in safety before the start of the works, especially in the area close to the ceiling and the stage arch. Furthermore, during the intervention phase, monitoring was guaranteed to employ flexmeters, crack gauges and hygrometers.

Fig. 4. Extensive methodology on the sample of historical Romagn Remilia-

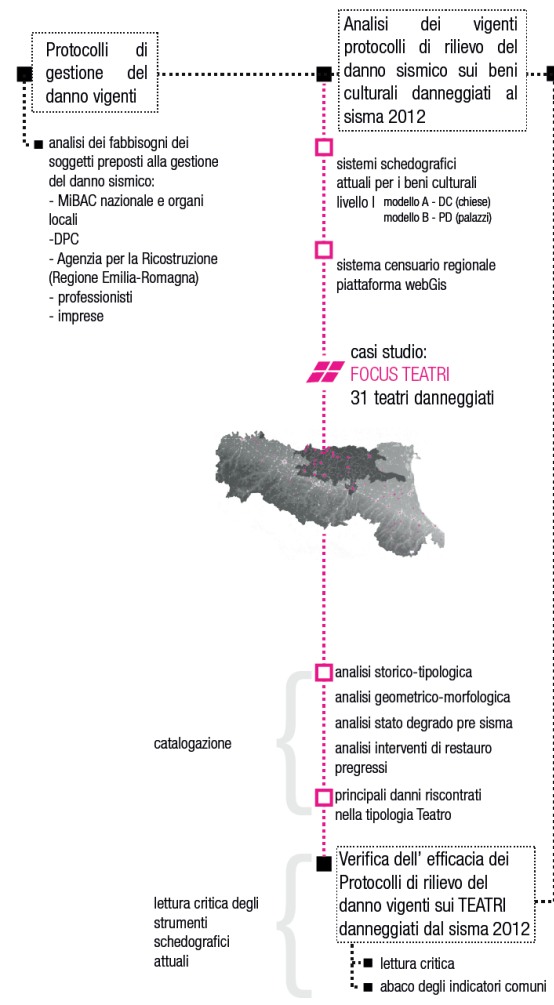




\section{Zero Pilot case}

In order to achieve verification of the extensive integrated methodology, the pilot zero cases of the teatro comunale of Novi di Modena, not surveyed beforehand, will be applied. Methodologically, for this case, the survey phases have been planned to follow a multi-criteria and multi-scale analysis workflow, which will be verified and implemented in the operational phase. Based on the survey operations on the architectural building is the classification matrix that identifies three volumetric macro-blocks: foyer, cavea -tripartite stalls, stage and backstage- and dressing rooms as distinctive sections of the theatre typology both in the morphological, structural-static and plant layout. Analytical sampling has shown that the static behaviour of the foyers and dressing rooms can be conformed to that of a building, unlike the cavea whose static-dynamic response is alike to a church hall.

Starting from a GIS cartographic classification through the platform of the Segretariato Regionale, it moves on to define the topographic grid to control tool and support the LIDAR survey. The stratigraphic reading of the macro-sections allows to define, therefore, the classification of macro-elements, on which to categorize the point cloud, useful to inform the elaborate modelling and management of geometric and semantic information of the relative BIM model [Scianna, La Guardia, Scaduto 2016 ]. The integration with photogrammetric and thermographic technique is programmed to investigate in detail the most damaged surfaces, especially in the area of the redoubt, stage, stage arch and ceiling (in the accessible points). The surfaces mapping, preceded by preliminary sketch, allows a detailed classification of portions of the Theatre, identifying the possible interventions suffered over time.
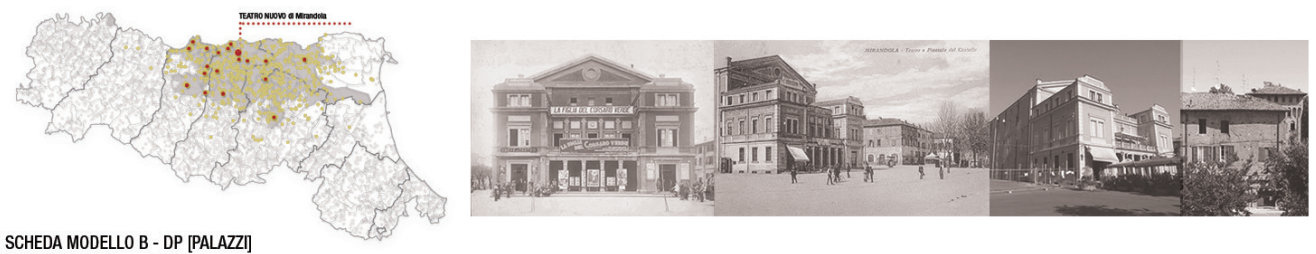

SCHEDA MODELLO B - DP [PALAZZI] D.P.C.M 23 Febbraio 2006 Abaco dei Meccanismi di collasso

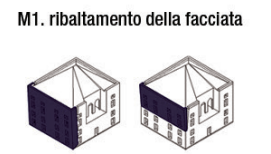

M3. rottura a flessione delle pareti

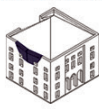

Livelli di Danno

1 - danno lieve

2 - danno moderato

3 - danno grave

4 - danno molto grave
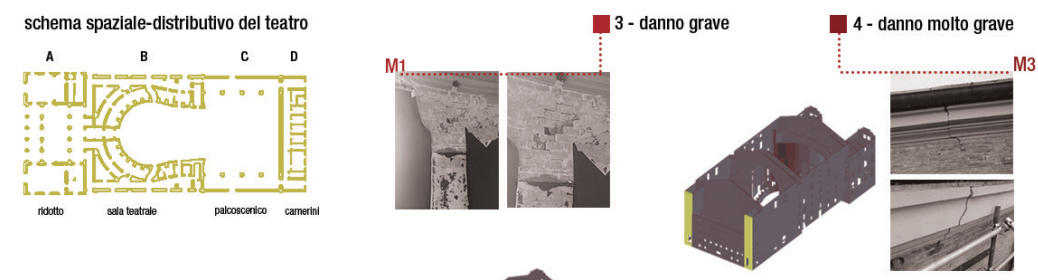

\section{Results}

The systematization of data collected from Ministry forms and regional GIS databases, semantic information collected from documentary and archive sources includes the integration of geometric-stratigraphic information gained from surveys of the single theatres. Through this ongoing step, comparative analysis of techniques, technologies and methods applied will map to synthesize and classify the idioms of representation, codes of cataloguing 
Fig. 6. Classification of data collected through the Access database: analysis of data on the type of masonry with the mechanisms of collapse verified.

\section{Analisi critica della scheda}

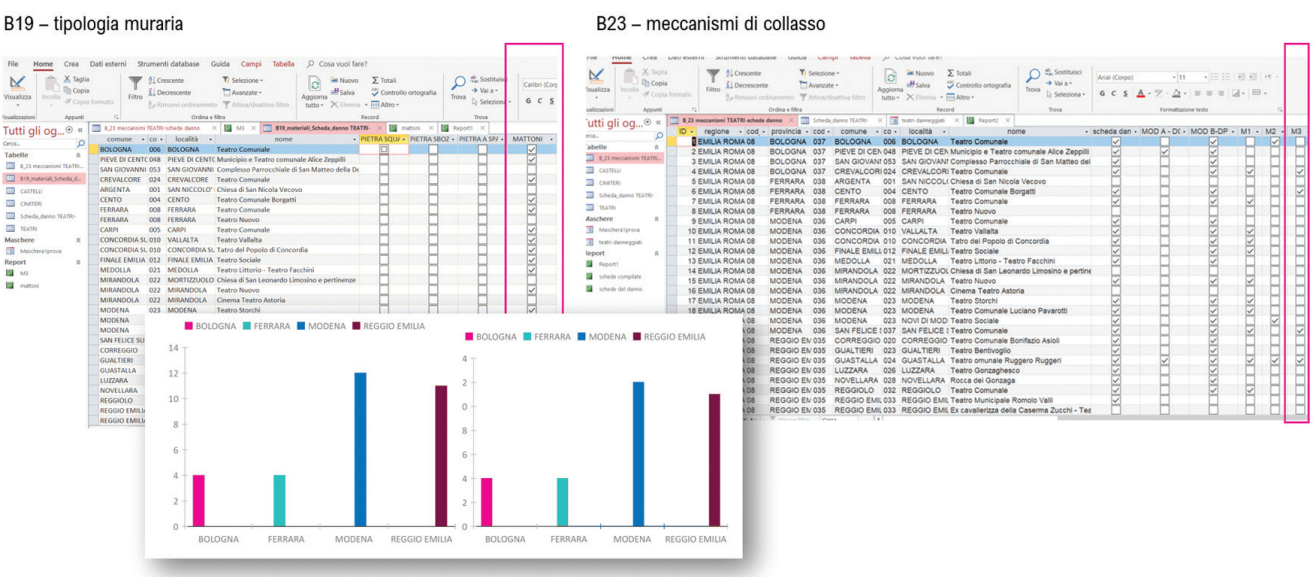

and methodological syntax of the integrated approach, aimed at the construction and verification of the protocol. Finally, in providing an insight into research, it should be explained that the operational implementation of the information systematization using the INCEPTION HBIM platform is to be achieved. The development of a sample of if models, loaded in the interoperable platform, is aimed at the implementation of qualitative and quantitative information, providing competent authorities and professionals with a single integrated digital tool. In order to implement the seismic risk information within ifc models, they will be developed according to the protocol and classified in the defined macro-elements developed on taxonomic matrix. Once the extensive homogeneous analysis criteria on the sampling of damaged theatres have been defined, the research proposes the development of a set of rules, aimed at Clash Detection and Code Checking of the BIM model, for the verification and validation of the model [Balzani, Suppa 2020].

\begin{tabular}{|c|c|c|c|c|c|c|c|c|}
\hline \multicolumn{2}{|l|}{ ID Teatro } & \multirow{2}{*}{ schede del danno } & \multirow{2}{*}{\begin{tabular}{|l} 
verifica rilievo geometrico $2 \mathrm{~d}$ esistente \\
\end{tabular}} & \multirow{2}{*}{ stazione totale } & \multirow{2}{*}{ laser scanner } & \multirow{2}{*}{$\begin{array}{r}\text { fotocamera } \\
0 .\end{array}$} & \multirow[t]{2}{*}{ voli drone } & \multirow[t]{2}{*}{ temocamera } \\
\hline FE_CENTO & \begin{tabular}{|l|} 
Teatro Comunale \\
Borgattl
\end{tabular} & & & & & & & \\
\hline MO_MIRANDOL & Teatro Nuovo & & 彭 & 핟 & & (6) & (3) & \\
\hline RE_GUASTALLA & \begin{tabular}{|l} 
Teatro \\
Comunale R. \\
Ruggeri
\end{tabular} & & 師舟 & (ㅇ․ & & 0 & & \\
\hline RE_NOVELLARA & $\begin{array}{l}\text { Teatro Rocca } \\
\text { dei Gonzaga }\end{array}$ & $\angle 8$ & 咥 & (ㅂ) & & రి & & \\
\hline RE_REGGIOLO & $\begin{array}{l}\text { Taetro Comuale } \\
\text { G. Rinaldi }\end{array}$ & $\angle B$ & 胡 & (⿴) & & రి & & \\
\hline
\end{tabular}

\section{References}

Balzani Marcello, Raco Fabiana, Suppa Martina (2019). Protocolli di acquisizione e gestione dati per la documentazione, rappresentazione e conservazione del patrimonio culturale danneggiato dal sisma. In Paesaggio Urbano, I, 20 I 9, pp. I6I-I69.

Balzani Marcello, Suppa Martina (2020). Integrated survey procedures: a methodological approach for documentation and representation applied to Emilia-Romagna theatres. In International Conference, HeriTech 2020, The Future of Heritage Science and Technologies, International Conference, Florence, 2020 (being published)

Bold John and ed. (2009). Guidance on inventory and documentation. Council of Europe, 2009. 
Bolognesi Cecilia Maria (2019). Un parco di sperimentazioni: Applicazioni di rilievo e modellazione per la costruzione di ambienti virtuali in Cultural Heritage. In Paesaggio Urbano, 3, 2019, pp. 57-67.

Bondoni Simonetta Maria (1982). Teatri storici in Emilia-Romagna. Bologna: Grafis.

Bonsma Peter, Bonsma Iveta, Sebastian Rizal, Maietti Federica et al. (20 I6). Roadmap for IT research on a Heritage-BIM Interoperable Platform within INCEPTION. In Borg Ruben Paul, Gauci Paul, Staines Cyril Spiteri (eds.). Proceedings of the International Conference, SBE, Malta, Europe and the Mediterranean:Towards a Sustainable Built Environment, I 6th- I 8th March 20 I 6-Valletta: Gutenberg Press, pp. 283-290.

Cocchi Enrico (2016). La ricostruzione post sisma 2012 in Emilia-Romagna: Quale contributo alla resilienza del territorio? In AA.W. Pianificazione strategica vulnerabilità urbana e analisi degli edifici strategici, Santarcangelo di Romagna: Maggioli Editore, pp. $12-14$.

Coïsson Eva, Ferrari Lia (2019). Predisposizione e studio di modelli specifici ad implementazione degli strumenti esistenti: scheda per la valutazione dei primi interventi di messa in sicurezza e rilievo del danno per tipologie architettoniche specifiche (teatri, castelli, cimiteri). In Paesaggio Urbano, I, 2019, pp. I53-I59.

DPCM 23 Febbraio 2006, n. 55 Approvazione dei modelli per il rilevamento dei danni, a seguito di eventi calamitosi, ai beni appartenenti al patrimonio culturale.

Farneti Fauzia, Van Riel Silvio (1975). L'architettura teatrale in Romagna 1757- 1857. Firenze: UNIEDIT.

Kioussi Anastasia, Karoglou Maria, Labropoulos Kyriakos, Bakolas Asterios, Moropoulou Antonia (20I2). Integrated documentation protocols able to support decision making process in cultural heritage protection. In Roko Žarnic, Vlatka Rajcic, Barbara Vodopivec. Heritage Protection. From Documentation to Interventions. Proceedings of the EU-CHIC International Conference on Cultural Heritage Preservation, Ljubljana, Slovenia 2012, pp. I29-131.

Libro Antonino (20 I 9). Il rilievo del danno al patrimonio storico-artistico e i primi interventi di messa in sicurezza. In Paesaggio Urbano, I, 2019, pp. 147-151.

Maietti Ferderica (2019). Survey and representation of historical surfaces: the coulours of Jodfhpur. In Balzani Marcello, Minakshi Jain, Rossato Luca. Between History and Memory, the Blue Jodhpur. Experiences of integrated documentation and survey techiniques. Santarcangelo di Romagna: Maggioli Editore.

Maietti Federica, Ferrari Federico, Medici Marco, Balzani Marcello (20I6). 3D integrated laser scanner survey and modelling for accessing and understanding European cultural assets. In Ruben Paul Borg, Paul Gauci, Spiteri Staines Staines. Proceedings of the International Conference, SBE, Malta, Europe and the Mediterranean:Towards a Sustainable Built Environment, I 6th- I 8th March 20 16. Valletta: Gutenberg Press, pp. 317-324.

Parrinello Sandro (20 I0). II rilievo del complesso di Monte Senario. Strategie per la documentazione e la valorizzazione. In Bertocci Stefano, Parrinello Sandro. Architettura Eremitica: Sistemi Progettuali e Paesaggi Culturali. Firenze: Edifir-Edizioni, pp. 17-33.

PP., 2 febbraio 2009, n. 617, Istruzioni per l'applicazione delle "Norme tecniche per le Costruzioni", capitolo C8 e l'Allegato A.

Remondino Fabio (20 I I). Rilievo e modellazione 3D di siti e architetture complesse. In DisegnareCon. Tecnologie per la comunicazione del patrimonio culturale, 8, 201 I, 4 .

\section{Website}

https://geoportale.regione.emilia-romagna.it/it

https://www.patrimonioculturale https://www.patrimonioculturale-erit/webgis/

https://sites.google.com/view/statsbyggs-bim-manual-2-0-sbm2/hjem, Statsbygg BIM Manual 2.0, EU BIMTask Group - 2019.

https://www.inception-project.eu/en, INCEPTION -Inclusive Cultural Heritage in Europe through 3D semantic modelling, Horizon 2020.

\section{Authors}

Marcello Balzani, Università degli Studi di Ferrara, bzm@unife.it

Martina Suppa, Università degli Studi di Ferrara, martina.suppa@unife.it

To cite this chapter. Balzani Marcello, Suppa Martina (2020). Una metodologia integrata per la documentazione e rappresentazione dei Teatri emiliani danneggiati dal sisma del 2012/An integrated methodology for the documentation and representation of the Emilia-Romagna damaged theatres by the 2012 earthquake. In Arena A., Arena M., Brandolino R.G., Colistra D., Ginex G., Mediati D., Nucifora S., Raffa P. (a cura di). Connettere. Un disegno per annodare e tessere. Atti del $42^{\circ}$ Convegno Internazionale dei Docenti delle Discipline della Rappresentazione/Connecting. Drawing for weaving relationships. Proceedings of the 42 th International Conference of Representation Disciplines Teachers. Milano: FrancoAngeli, pp. 1644 - 1659. 